\title{
Voltammetric sensor based on long alkyl chain tetraalkylammonium ionic liquids comprising ascorbate anion for determination of nitrite
}

\author{
Tomasz Rębiś ${ }^{1}$ - Michał Niemczak ${ }^{2}$ - Patrycja Płócienniczak ${ }^{1}$. Juliusz Pernak ${ }^{2}$ - Grzegorz Milczarek ${ }^{1}$
}

Received: 4 November 2020 / Accepted: 11 January 2021 / Published online: 27 January 2021

(C) The Author(s) 2021

\begin{abstract}
An electrochemical sensor was fabricated utilizing ionic liquids possessing cations with long alkyl chains such as trimethyl octadecylammonium and behenyl trimethylammonium and ascorbate anion. The ionic liquids were drop-coated onto the electrode. Thin modifying layers were prepared. Cyclic voltammetric investigations revealed electrostatic interactions between the electrochemical probes and the modified surface, proving that a positive charge was established at the film surface. Hence, negatively charged species such as nitrite can be pre-concentrated on the surface of presented modified electrodes. The fabricated electrodes have been used as a voltammetric sensor for nitrite. Due to the electrostatic accumulation properties of long alkyl cation, the assay exhibits a remarkable improvement in the voltammetric response toward nitrite oxidation. The influence of $\mathrm{pH}$ on the electrode response was thoroughly investigated, and the mechanism of the electrode was established. The developed sensor showed a linear electrochemical response in the range 1.0-50 $\mu \mathrm{M}$ with a detection limit of $0.1 \mu \mathrm{M}$. The electrode revealed good storage stability, reproducibility, and anti-interference ability. The determination of nitrite performed in curing salts brought satisfactory results.
\end{abstract}

Keywords Long alkyl chain tetraalkylammonium ionic liquid $\cdot$ Nitrite $\cdot$ Voltammetry $\cdot$ Curing salt

\section{Introduction}

Nitrite is an ion commonly found in food, soil, water, and different physiological systems. Great amounts of nitrite compounds are used in food technology, especially as preservatives. Nitrite is used as an additive in cured products to obtain the characteristic red color and desirable flavor $[1,2]$. Nitrite is potentially toxic and irritant, which is why it is considered a pollutant and a cause of deterioration of human health [3]. The excess level of nitrite in the blood is hazardous. Different studies have proved that nitrite can undergo a reaction with secondary amines to produce mostly carcinogenic

Tomasz Rębiś

tomasz.rebis@put.poznan.pl

1 Institute of Chemistry and Technical Electrochemistry, Poznan University of Technology, Berdychowo 4, 60-965 Poznan, Poland

2 Department of Chemical Technology, Poznan University of Technology, ul. Berdychowo 4, 60-965 Poznan, Poland nitrosamines [4]. Therefore, reliable and accurate determination of nitrate substances in the environment is very important [5-7].

To date, numerous methods including chromatography, chemiluminescence, spectrophotometry, and electrochemical sensors have been developed to detect nitrite $[3,4,8]$. Lowcost instrumentation, fast response, and simplicity of use made the electrochemical approach a useful tool for the determination of nitrite [6, 9-12]. However, the voltammetric determination of nitrite encounters difficulties associated with slow electron transfer kinetics, which in turn requires the large overpotentials to be involved. Therefore, to obtain better sensitivity and lower overpotential for the oxidation of various compounds, it is necessary to modify the electrode surface with electroactive materials [5, 7, 13-15].

Owing to the need for a high performance of the electrochemical nitrite sensor, the surface modifications of the electrode are usually applied to boost their sensitivity and to enhance selective interactions between the sensing layer and analytes. In recent years, various chemically modified electrodes have been proposed for the determination of nitrites. For instance, poly(3,4-ethylenedioxythiophene) (PEDOT) 
hollow microflower was applied [16]. Platinum nanoparticles embedded on polypyrrole matrix were also reported as a sensor for nitrite detection [17]. Various redox mediators such as metalled phthalocyanines or porphyrazines were used to build nitrite sensitive modified electrodes. In particular, macrocycles bearing transition metal ions such as $\mathrm{Co}, \mathrm{Fe}$, and $\mathrm{Ni}$ in their cores and involving reversible redox transitions are considered to be suitable for nitrite determination $[3,7$, 18-20]. Recently, composites consisting of graphene nanoparticles and precious metal have also been given attention $[6,9]$. Furthermore, papers describing modified electrodes based on various nickel materials enabling electrocatalytic detection of nitrite have been published [7, 13, 19, 21].

Over the last few years, the use of ionic liquids (ILs) for electrochemical sensing has gained momentum. ILs have demonstrated many attractive physicochemical properties such as good ionic conductivity, high chemical and thermal stability, and wide electrochemical window. It has been presented that ILs can be effectively used as the high-performance modifiers for the development of modified electrodes [22-24]. Recent results suggest that the ionic liquid/graphene modified electrode can be utilized for simultaneous electrochemical sensing of thallium, lead, and mercury [25]. Moreover, the electrochemical oxidation of NADH on a glassy carbon electrode modified by IL (1-butyl-3-methylimidazolium tetrafluoroborate, $\mathrm{BMIM} \cdot \mathrm{BF}_{4}$ ) and multi-walled carbon nanotubes with a polymeric matrix of chitosan was also reported [26]. The IL applied as active material in the preparation of modified electrode for nitrite oxidation has also been evaluated. For instance, Wang et al. presented Prussian blue/1-butyl-3-methylimidazolium tetrafluoroborategraphite felt electrodes for the efficient electrocatalytic determination of nitrite [27]. Moreover, the electrode with ionic liquid n-octylpyridinum hexafluorophosphate (OPFP) and single-walled carbon nanotube has also been proposed [28].

In this work, the electrodes were modified with thin layers of ILs containing cation substituted with long alkyl chains such as trimethyl octadecylammonium $\left(\mathrm{C}_{18} \mathrm{TMA}\right.$ ASC) and behenyl trimethylammonium $\left(\mathrm{C}_{22}\right.$ TMA-ASC). As a result of the proposed modification, the oxidation current of nitrite increases significantly when compared to the currents recorded on an unmodified glassy carbon (GC) electrode. The increase of recorded signals is caused by electrostatic interactions between the nitrate anion $\left(\mathrm{NO}_{2}{ }^{-}\right)$and the cationic form of ionic liquids covering the electrode surface. The practical application of the presented sensor was evaluated in commercially available curing salt samples under validated conditions. To the best of the authors' knowledge, there is yet no report regarding the application of long alkyl ammonium ILs in the development of electrochemical sensors.

\section{Experimental part}

\section{Materials and reagents}

ILs comprising of ascorbate anion and cation substituted with long alkyl chain such as trimethyl octadecylammonium $\left(\mathrm{C}_{18}\right.$ TMA-ASC) and behenyl trimethylammonium $\left(\mathrm{C}_{22}\right.$ TMA-ASC) were synthesized according to a previously published procedure [29]. Both ILs were synthesized under mild conditions using ion-exchange resin, which allows products deprived of impurities in the form of chlorides to be obtained. Firstly, the appropriate quaternary ammonium chloride was dissolved in ethanol and then mixed with the anionic resin Dowex Monosphere 550A in the form of an ethanolic suspension. The mixture was stirred for $1 \mathrm{~h}$ at $25^{\circ} \mathrm{C}$, and thereby, the chloride anions were replaced with hydroxide ions. Subsequently, the intermediates (organic ammonium hydroxides) were neutralized with ascorbic acid in a 1:1 stoichiometric ratio using an Easy-Max reactor. Then, after evaporation of the solvent, the obtained products were dried under a vacuum at $25{ }^{\circ} \mathrm{C}$ for $24 \mathrm{~h}$ and stored over $\mathrm{P}_{4} \mathrm{O}_{10}$ at $-20{ }^{\circ} \mathrm{C}$. Structures of ILs are presented in Scheme 1.

Sodium nitrite $\left(\mathrm{NaNO}_{2}\right)$ and dimethylformamide (DMF) were purchased from Sigma-Aldrich. Perchloric acid, monosodium, and disodium phosphates for the preparation of phosphate buffer (PB) were provided by Avantor POCH (Gliwice, Poland). All these compounds were of reagent grade and were used without further purification.

Britton-Robinson buffers were prepared by adding the desired volume of $0.2 \mathrm{M} \mathrm{NaOH}$ to the mixture of $0.04 \mathrm{M}$ $\mathrm{H}_{3} \mathrm{BO}_{3}, 0.04 \mathrm{M} \mathrm{H}_{3} \mathrm{PO}_{4}$, and $0.04 \mathrm{M} \mathrm{CH}_{3} \mathrm{COOH}$. All solutions were prepared using deionized water.

The commercial curing salts ( 3 samples) were purchased from a local supermarket. To fit within a proper nitrite concentration, the accurate mass of the salt sample was weighed, dissolved with electrolyte, and diluted to $25.0 \mathrm{~mL}$ in a calibrated flask. The nitrite determination was carried out by differential pulse voltammetric measurements (DPVs) using the standard addition method. The first voltammetric signal was due to the addition of the curing salt solution. Next, the aliquots $(5 \mu \mathrm{M})$ of nitrites were added to create a standard addition plot. The concentration of nitrites in curing salt is the reading of the unknown.

\section{Electrochemical methods}

Electrochemical measurements were performed using a $\mu$ Autolab III (ECO Chemie, The Netherlands) potentiostat/ galvanostat. A typical three-electrode configuration was used with $\mathrm{Ag} / \mathrm{AgCl} / 3 \mathrm{M} \mathrm{KCl}$ as a reference electrode, a Pt wire as a counter electrode, and a glassy carbon disk $(\mathrm{GC}, \mathrm{d}=3 \mathrm{~mm}$, BasiINC, USA) as working electrode. Before the electrochemical experiments, a GC electrode had been polished with 
Scheme 1 Chemical structures of the studied ILs<smiles>C[C@H](CO)C1OC(=O)C([O-])=C1O</smiles>

C22TMA-ASC<smiles>CCCCCCCCCCCCCCCCCCC[N+](C)(C)C</smiles>

C $_{18}$ TMA-ASC<smiles>C[C@H](CO)C1OC(=O)C([O-])=C1O</smiles>

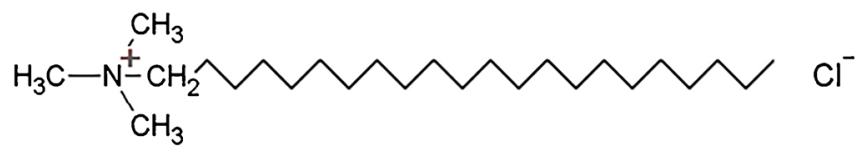

C22TMA-CI aqueous $50 \mathrm{~nm} \mathrm{Al}_{2} \mathrm{O}_{3}$ slurry (Buehler) on a polishing cloth, followed by subsequent washing in an ultrasonic bath with acetone for $10 \mathrm{~min}$ in order to remove any trace impurities.

\section{Fabrication of $\mathrm{GC} / \mathrm{C}_{18} \mathrm{TMA}-\mathrm{ASC}, \mathrm{GC} / \mathrm{C}_{22} \mathrm{TMA}-\mathrm{Cl}$, and $\mathrm{GC} / \mathrm{C}_{22}$ TMA-ASC modified electrodes}

In order to modify the surface of the GC electrode, $10 \mathrm{mM}$ solutions of studied ILs were dissolved in DMF in the first step. Next, the thin layers were deposited onto the GC by dropping 1 , or $3 \mu \mathrm{L}$ of each IL. The surfaces were subsequently dried at room temperature for ca. $1 \mathrm{~h}$. The electrodes prepared this way were ready to use in electrochemical measurements. As a pretreatment, the electrodes were immersed in pure phosphate buffer ( $\mathrm{PB}, \mathrm{pH}$ 7.4) and scanned from -0.2 to $0.6 \mathrm{~V}$ ( 20 cycles) to obtain a stable cyclic voltammogram (CV). Final electrodes were denoted as $\mathrm{GC} / \mathrm{C}_{18} \mathrm{TMA}-\mathrm{ASC}$, $\mathrm{GC} / \mathrm{C}_{22}$ TMA-Cl, and $\mathrm{GC} / \mathrm{C}_{22}$ TMA-ASC.

\section{Results and discussion}

\section{Electrochemical characterization of $\mathrm{GC} / \mathrm{C}_{18} \mathrm{TMA}-\mathrm{ASC}$, $\mathrm{GC} / \mathrm{C}_{22} \mathrm{TMA}-\mathrm{Cl}$, and $\mathrm{GC} / \mathrm{C}_{22}$ TMA-ASC electrodes}

In Fig. 1, cyclic voltammograms for $\mathrm{GC} / \mathrm{C}_{22}$ TMA-ASC electrode recorded in $\mathrm{PB}$ buffer in the presence of redox markers $\mathrm{Ru}\left(\mathrm{NH}_{3}\right)_{6}{ }^{3+}$ and $\mathrm{Fe}(\mathrm{CN})_{6}^{3-/ 4-}$ are shown. According to the results, a decrease in current peaks is observed in the presence of both positively charged $\mathrm{Ru}\left(\mathrm{NH}_{3}\right)_{6}{ }^{3+}$ and negatively charged $\mathrm{Fe}(\mathrm{CN})_{6}{ }^{3-/ 4-}$. The observed behavior is particularly pronounced in the case of $\mathrm{Ru}\left(\mathrm{NH}_{3}\right)_{6}{ }^{3+}$. These results indicate a partial blocking of the electrode surface by a thin layer of $\mathrm{C}_{22}$ TMA-ASC modifier [30, 31]. Since the modifying IL has a long hydrophobic chain, which is a cation, electrostatic interactions between the thin layer of the modifier and ionic redox compounds can be expected. In the case of $\mathrm{Ru}\left(\mathrm{NH}_{3}\right)_{6}{ }^{3+}$, a significant increase in peak separation from 63 to $172 \mathrm{mV}$ (Fig. 1, curves a and b) is observed at the GC/ $\mathrm{C}_{22}$ TMA-ASC electrode, which suggests coulombic repulsion of the positively charged electrode surface with $\mathrm{Ru}\left(\mathrm{NH}_{3}\right)_{6}{ }^{3+}$ cation.

The opposite effect is observed when an anionic marker $\left(\mathrm{Fe}(\mathrm{CN})_{6}^{3-/ 4-}\right)$ is applied. A slight decrease in the separation

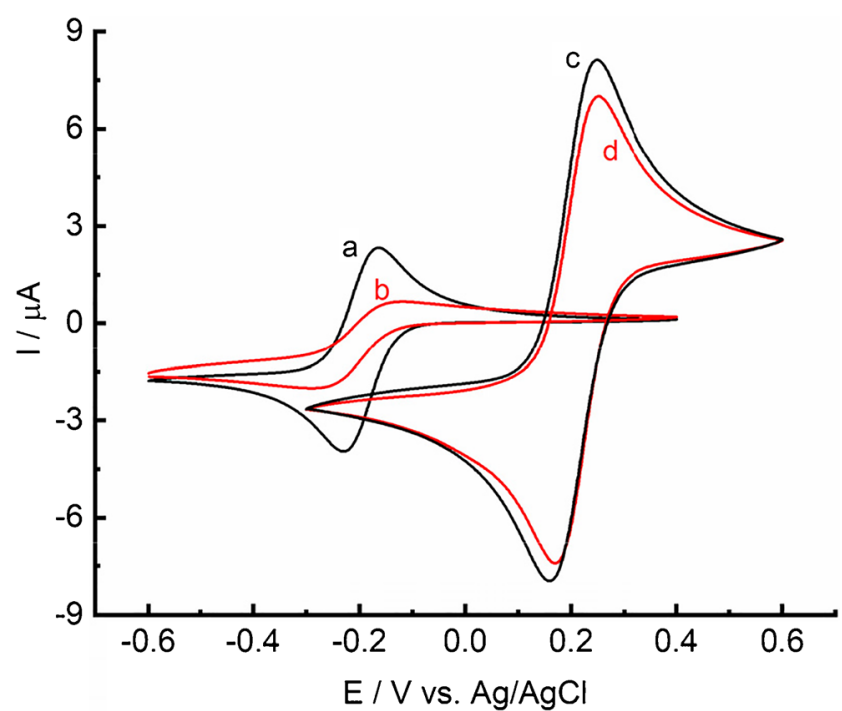

Fig. $1 \mathrm{CVs}$ in the presence of $1 \mathrm{mM}$ of $\mathrm{Ru}\left(\mathrm{NH}_{3}\right)_{6}{ }^{3+}$ recorded at bare $\mathrm{GC}$ (a) and GC/C 22 TMA-ASC (b) as well as CVs in the presence of $1 \mathrm{mM}$ $\mathrm{Fe}(\mathrm{CN})_{6}{ }^{3-/ 4-}$ recorded at bare $\mathrm{GC}(\mathrm{c})$ and $\mathrm{GC} / \mathrm{C}_{22}$ TMA-ASC (d). The supporting electrolyte was $\mathrm{PB}$ solution ( $\mathrm{pH}$ 7.4). Scan rate $10 \mathrm{mV} \mathrm{s}^{-1}$ 
of peaks from 80 to $75 \mathrm{mV}$ is observed, which may indicate adsorption of $\mathrm{Fe}(\mathrm{CN})_{6}{ }^{3-/ 4-}$ on the electrode surface (Fig. 1, curves $\mathrm{c}$ and $\mathrm{d}$ ). This effect can be ascribed to the electrostatic attraction of the $\mathrm{Fe}(\mathrm{CN})_{6}{ }^{3-/ 4-}$ anion by the behenyl trimethylammonium cation. The $\mathrm{CVs}$ recorded for both $\mathrm{Fe}(\mathrm{CN})_{6}{ }^{3-/ 4-}$ and $\mathrm{Ru}\left(\mathrm{NH}_{3}\right)_{6}{ }^{3+}$ redox markers at $\mathrm{GC} /$ $\mathrm{C}_{18}$ TMA-ASC and $\mathrm{GC} / \mathrm{C}_{22}$ TMA-Cl electrodes are displayed in Fig. S1 and Fig. S2, respectively. As it can be seen, similar results to those at $\mathrm{GC} / \mathrm{C}_{22}$ TMA-ASC are observed. According to the given data, the influence of electrostatic interactions is the weakest for the $\mathrm{GC} / \mathrm{C}_{18}$ TMA-ASC electrode. Table 1 summarizes the peak separation for $\mathrm{Fe}(\mathrm{CN})_{6}{ }^{3-/ 4-}$ and $\mathrm{Ru}\left(\mathrm{NH}_{3}\right)_{6}{ }^{3+}$ redox markers recorded for the $\mathrm{GC} / \mathrm{C}_{18} \mathrm{TMA}-$ ASC, GC/C 22 TMA-Cl, and $\mathrm{GC} / \mathrm{C}_{22}$ TMA-ASC electrodes tested.

\section{Voltammetric response of nitrite at the $\mathrm{GC} / \mathrm{C}_{18} \mathrm{TMA}$ - ASC, $\mathrm{GC} / \mathrm{C}_{22} \mathrm{TMA}-\mathrm{Cl}$, and $\mathrm{GC} / \mathrm{C}_{22} \mathrm{TMA}-\mathrm{ASC}$ electrodes}

The DPV responses for the oxidation of $10 \mu \mathrm{M} \mathrm{NaNO}{ }_{2}$ at bare GC, GC/C 18 TMA-ASC, GC/C 22 TMA-Cl, and GC/C 22 TMAASC were studied, and the results are presented in Fig. 2. As shown, all the modified electrodes reveal a well-defined and sharp peak that appears in the presence of $10 \mu \mathrm{M} \mathrm{NaNO}$. The voltammetric signals are significantly higher as compared to the bare GC electrode. Moreover, the peaks for $\mathrm{NaNO}_{2}$ oxidation at the modified electrodes were recorded at lower potentials as compared to the bare GC. Such behavior suggests the adsorption/pre-concentration ability of the modified layers toward $\mathrm{NaNO}_{2}$. Poor current response in the case of $\mathrm{GC}$ is related to sluggish kinetics for nitrite oxidation as previously reported for this material [7, 20]. Among the electrodes studied here, the $\mathrm{GC} / \mathrm{C}_{22} \mathrm{TMA}-\mathrm{ASC}$ showed the highest voltammetric peak. These results indicate much higher sensitivity of the $\mathrm{GC} / \mathrm{C}_{22} \mathrm{TMA}-\mathrm{ASC}$ electrode than that of a bare $\mathrm{GC}$. The improved electrochemical response recorded at $\mathrm{GC} /$ $\mathrm{C}_{22}$ TMA-ASC for nitrite can be assigned to the positively charged long alkyl behenyl trimethylammonium groups on the surface of the electrode. The electrostatic accumulation of nitrite at the electrode surface can promote its surface concentration and, consequently, boost the oxidation signal of $\mathrm{NaNO}_{2}$.

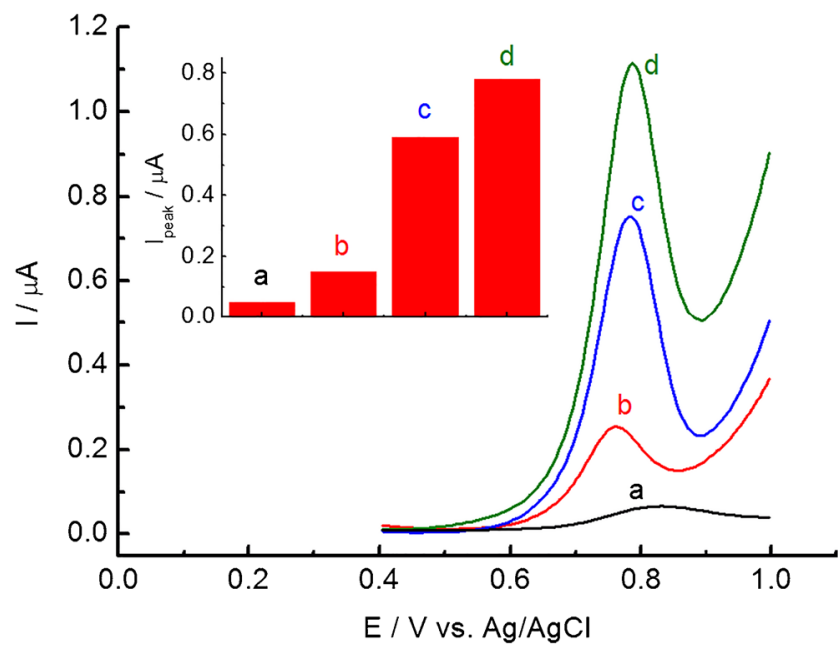

Fig. 2 DPV response for bare GC (a), GC/C 18 TMA-ASC (b), GC/ $\mathrm{C}_{22}$ TMA-Cl (c), and GC/C 22 TMA-ASC (d) in the presence of $10 \mu \mathrm{M}$ $\mathrm{NaNO}_{2}$. The inset presents corresponding peak currents $\left(\mathrm{I}_{\text {peak }}\right)$ recorded in the presence of $10 \mu \mathrm{M} \mathrm{NaNO}_{2}$ at bare GC (a), GC/C 18 TMA-ASC (b), $\mathrm{GC} / \mathrm{C}_{22} \mathrm{TMA}-\mathrm{Cl}$ (c), and $\mathrm{GC} / \mathrm{C}_{22} \mathrm{TMA}-\mathrm{ASC}(\mathrm{d})$

To verify the influence of electrode thickness (mass loading) on the redox peak of nitrate oxidation, a series of DPV measurements were conducted in the presence of $5 \mu \mathrm{M}$ $\mathrm{NaNO}_{2}$. DPVs were recorded at the $\mathrm{GC} / \mathrm{C}_{22}$ TMA-ASC electrodes containing different modifier masses in the range from 5.5 to $16.5 \mu \mathrm{g}$. As shown in Fig. S3, the increase in the mass of the $\mathrm{C}_{22}$ TMA-ASC from 5.5 to $11.0 \mu \mathrm{g}$ causes the over twofold increase in the current signal, which indicates the enhanced accumulation effect of the electrode. However, the decrease in the peak current is observed when the electrode mass rises to $16.5 \mu \mathrm{g}$. It is probably related to the diffusion limitations that may appear at thick layers of the modifier [32]. Thus, $11.0 \mu \mathrm{g}$ of $\mathrm{C}_{22}$ TMA-ASC was chosen as the optimal mass and the electrode prepared in this way was used in further experimental studies.

\section{Effect of $\mathrm{pH}$, peak current, and scan rate at the GC/C 22 TMA-ASC electrode}

We also carried out the studies on the influence of $\mathrm{pH}$ on two variables such as peak current and peak potential, and the results are presented in Fig. 3. The obtained plots show clearly

Table 1 Values of $\Delta \mathrm{E}$ and $\mathrm{I}_{\text {peak }}$ for selected redox markers recorded at studied modified electrodes

\begin{tabular}{|c|c|c|c|c|c|}
\hline Redox marker & & $\mathrm{GC}$ & $\begin{array}{l}\mathrm{GC} / \mathrm{C}_{22} \mathrm{TMA}^{-} \\
\mathrm{ASC}\end{array}$ & $\begin{array}{l}\mathrm{GC} / \mathrm{C}_{18} \mathrm{TMA}- \\
\mathrm{ASC}\end{array}$ & $\begin{array}{l}\mathrm{GC} / \mathrm{C}_{22} \text { TMA- } \\
\mathrm{Cl}\end{array}$ \\
\hline \multirow[t]{2}{*}{$\mathrm{Fe}(\mathrm{CN})_{6}^{3-/ 4-}$} & $\Delta \mathrm{E} / \mathrm{mV}$ & 80 & 75 & 80 & 79 \\
\hline & $\mathrm{I}_{\text {peak }} / \mu \mathrm{A}$ & 10.4 & 9.5 & 9.7 & 10.0 \\
\hline \multirow[t]{2}{*}{$\mathrm{Ru}\left(\mathrm{NH}_{3}\right)_{6}{ }^{3+}$} & $\Delta \mathrm{E} / \mathrm{mV}$ & 63 & 172 & 120 & 165 \\
\hline & $\mathrm{I}_{\text {peak }} / \mu \mathrm{A}$ & 4.1 & 1.4 & 3.8 & 2.1 \\
\hline
\end{tabular}




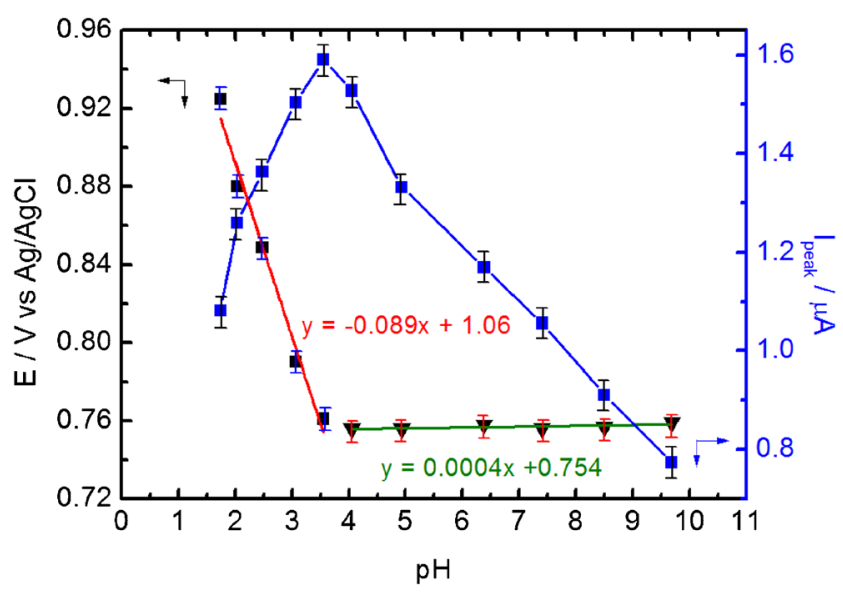

Fig. 3 The influence of $\mathrm{pH}$ on the peak potential and the peak current of $\mathrm{NaNO}_{2}$ oxidation $(\mathrm{c}=10 \mu \mathrm{M})$ at the $\mathrm{GC} / \mathrm{C}_{22} \mathrm{TMA}-\mathrm{ASC}$ electrode $(n=3)$

that at low $\mathrm{pH}$ (from 1.0 to 3.5 ) we can observe a significant increase in peak current with parallelly decreasing peak potential. At higher $\mathrm{pH}$ values (between 3.5 and 9.6), the peak potential remains almost constant; however, the peak current starts to decrease significantly. The shift of the peak potential as a function of $\mathrm{pH}$ suggests that protons participate in redox reaction in low $\mathrm{pH}$. However, the electrode mechanism in high $\mathrm{pH}$ does not involve protons.

$\mathrm{HNO}_{2}$ is a week acid with $\mathrm{pK}_{\mathrm{a}}$ equal to 3.3. Hence, at $\mathrm{pH}$ below 3.3 nitrous acid exists in protonated form according to chemical equilibrium (Eq. 1):

$\mathrm{HNO}_{2}+\mathrm{H}_{2} \mathrm{O} \rightarrow \mathrm{NO}_{2}^{-}+\mathrm{H}_{3} \mathrm{O}^{+}$

The obtained results show that the protonation degree of nitrite strongly affects the nitrite oxidation. At low $\mathrm{pH}$, the molecular form of the weak acid is preferred, so that the electrostatic attraction between the cationic layer of the modifier and the anionic analyte can be limited. The higher the $\mathrm{pH}$, the higher the deprotonation; thus, electrostatic attraction between the electrode surface and analyte increases. As a result, the oxidation peak remarkably increased when the $\mathrm{pH}$ went up and reached the maximum value of 3.5. Similar behavior was previously observed for a multiwalled carbon nanotube paste electrode modified with chitosan-functionalized silver nanoparticles, where charged amino groups were responsible for the electrostatic attraction of nitrites [33, 34]. On the other hand, it is well-known that nitrous acid is not stable in a strongly acidic electrolyte and can undergo the following disproportionation reaction (Eq. 2) [35]:

$2 \mathrm{H}^{+}+3 \mathrm{NO}_{2}{ }^{-} \rightarrow \mathrm{NO}_{3}{ }^{-}+2 \mathrm{NO}+\mathrm{H}_{2} \mathrm{O}$

Hence, the decrease in peak current at low $\mathrm{pH}$ can be also attributed to the low stability of $\mathrm{HNO}_{2}$ giving rise to the creation of $\mathrm{NO}$ and $\mathrm{NO}_{3}{ }^{-}$species. The gradual drop in the peak currents within the $\mathrm{pH}$ range 3.5 and 9.6 could be tentatively assigned to the decrease in the density of positively charged quaternary ammonium groups occurring at the increase of $\mathrm{pH}$. At higher $\mathrm{pH}$, quaternary ammonium hydroxide can be formed on the electrode surface that inhibits the electrostatic attraction of nitrite [29].

It was previously proved in many previous papers that the highest currents of nitrite oxidation were recorded in $\mathrm{pH}$ range between 3.0 and $4.0[5,13,34-38]$. In our study, the maximal peak current was observed at $\mathrm{pH}=3.5$; therefore, $\mathrm{pH} 3.5$ was selected as optimum for further voltammetric determination of nitrite.

The oxidation peak potential of nitrite shifted negatively at a slope of $-89 \mathrm{mV} / \mathrm{pH}$ in the range between 1.0 and 3.5. This value is close to that expected for oxidation involving $2 \mathrm{e}^{-}$and $3 \mathrm{H}^{+}(\sim 90 \mathrm{mV} / \mathrm{pH})$. Therefore, in an electrolyte with a low $\mathrm{pH}$, nitrite can be oxidized to nitrate according to the reaction presented in Eq. 3:

$\mathrm{HNO}_{2}+\mathrm{H}_{2} \mathrm{O} \rightarrow \mathrm{NO}_{3}^{-}+3 \mathrm{H}^{+}+2 \mathrm{e}^{-}$

In electrolytes with $\mathrm{pH}$ between 3.5 and 9.6, one-electron and zero-proton oxidation of nitrite to nitrogen dioxide should be expected according to Eq. 4 [39]:

$\mathrm{NO}_{2}{ }^{-}-\mathrm{e}^{-} \rightarrow \mathrm{NO}_{2}$

Electrode mechanism involving the formation of nitrate in strongly acidic media and formation of nitric oxide (IV) in more neutral electrolytes (at $\mathrm{pH}$ above $\mathrm{pK}_{\mathrm{a}}$ of $\mathrm{HNO}_{2}$ ) was also observed on boron-doped diamond (BDD) electrodes [40].

Cyclic voltammetry investigation with different scanning rates was performed to determine whether the $\mathrm{NaNO}_{2}$ oxidation is controlled by diffusion or adsorption processes on the GC/ $\mathrm{C}_{22}$ TMA-ASC electrode (Fig. 4 A). The oxidation peak current of nitrite increased with the increasing scanning rate. The linear relationship of the peak current versus scan rate was obtained from $10 \mathrm{mV} \mathrm{s}^{-1}$ to $50 \mathrm{mV} \mathrm{s}^{-1}$ with a correlation of $R^{2}=0.988$ (Fig. 4 B). However, a better linear correlation was observed when I was plotted vs. $v^{0.5}\left(R^{2}=0.996\right.$, Fig. 4 C). Such findings indicate that nitrite oxidation is strongly influenced by both diffusion and adsorption (accumulation). Hence, it can be assumed that the mixed diffusionadsorption process controls the oxidation at the $\mathrm{GC} /$ $\mathrm{C}_{22}$ TMA-ASC electrode surface.

\section{Nitrite detection by DPV using $\mathrm{GC} / \mathrm{C}_{22}$ TMA-ASC}

Furthermore, DPVs of $\mathrm{GC} / \mathrm{C}_{22} \mathrm{TMA}-\mathrm{ASC}$ in the electrolyte containing different concentrations of $\mathrm{NaNO}_{2}$ were recorded (Fig. 5). As shown, the anodic peak current shifts to higher values by increasing $\mathrm{NaNO}_{2}$ concentration. Such a response 
Fig. 4 (A) CVs recorded on a $\mathrm{GC} / \mathrm{C}_{22}$ TMA-ASC electrode in phosphate buffer ( $\mathrm{pH} 7.4)$ at sweep rates of 10 (a), 20 (b), 30 (c), 40 (d), and $50 \mathrm{mVs}^{-1}$ (e). (B) The relationship between peak current vs. scan rate (I vs. v), $n=$ 3. (C) The relationship between peak current vs. square root of scan rate (I vs. $\left.\mathrm{v}^{0.5}\right), n=3$

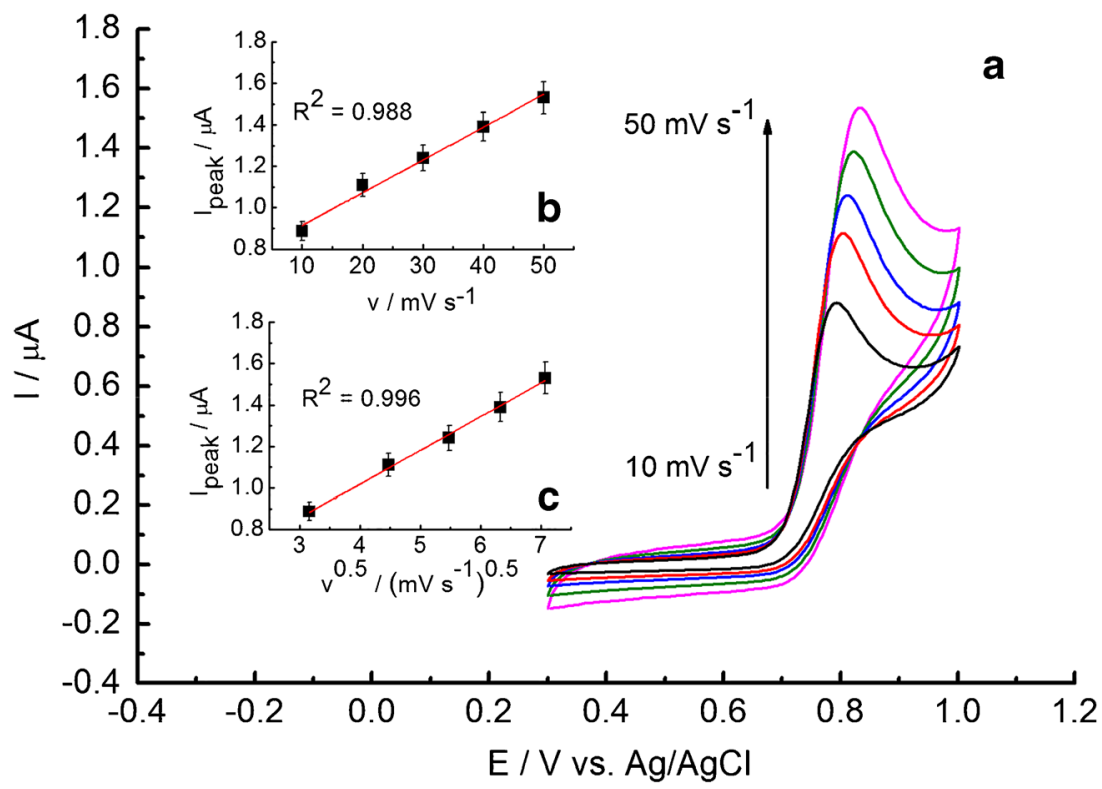

enables the quantitative analysis of nitrite at $\mathrm{GC} / \mathrm{C}_{22} \mathrm{TMA}$ ASC by DPV. The plot of anodic current vs. $\mathrm{NaNO}_{2}$ concentration is linear in the concentration range 0.5 to $50 \mu \mathrm{M}$, which fits the following equation: $\mathrm{I}_{\text {peak }}(\mu \mathrm{A})=0.024\left[\mathrm{NaNO}_{2}\right]$ $(\mu \mathrm{M})+0.003(\mu \mathrm{A}),\left(R^{2}=0.999\right)$. These results suggest that the prepared sensor possesses a high electroanalytical ability to determine nitrites.

Limits of detection (LOD) and limits of quantification (LOQ) were calculated from the plot of peak current versus concentration according to equations $\mathrm{LOD}=3 \mathrm{SD} / \mathrm{a}$ and LOQ $=10 \mathrm{SD} / \mathrm{a}$, where SD is the standard deviation of the intercept and $\mathrm{a}$ is the slope of the calibration plot. LOD and LOQ were calculated to be 0.10 and $0.36 \mu \mathrm{M}$, respectively. The

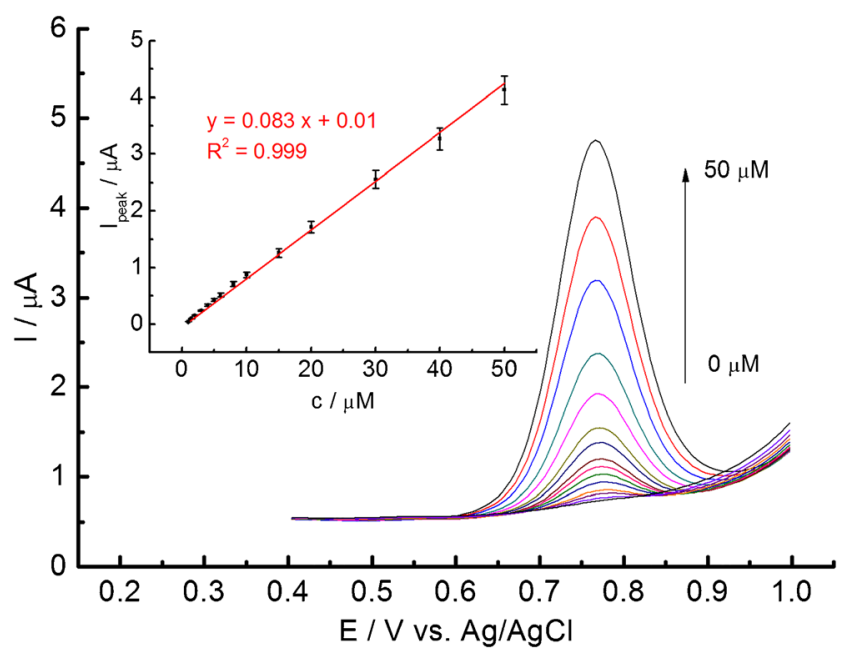

Fig. $5 \mathrm{DPV}$ curves to the increasing $\mathrm{NaNO}_{2}$ concentration at $\mathrm{GC} /$ $\mathrm{C}_{22}$ TMA-ASC modified electrode in $\mathrm{pH} 3.5$. The inset shows the corresponding $\mathrm{I}_{\text {peak }}$ Vs. c relationship $(n=3)$ sensitivity of the $\mathrm{GC} / \mathrm{C}_{22} \mathrm{TMA}-\mathrm{ASC}$ electrode was equal to $1185 \mu \mathrm{A} \mathrm{mM}^{-1} \mathrm{~cm}^{-2}\left(0.083 \mu \mathrm{A} \mu \mathrm{M}^{-1}\right)$.

\section{Repeatability, reproducibility, and storage stability of GC/C 22 TMA-ASC electrode}

The $\mathrm{GC} / \mathrm{C}_{22}$ TMA-ASC electrode presented satisfactory repeatability and reproducibility for $\mathrm{NaNO}_{2}$ determination. Ten determinations of $10 \mu \mathrm{M} \mathrm{NaNO}$ were performed for a single $\mathrm{GC} /$ $\mathrm{C}_{22}$ TMA-ASC (intra-day repeatability). The relative standard deviation (RSD) for 10 determinations of $\mathrm{NaNO}_{2}$ was $3.9 \%$. Moreover, the series of five different $\mathrm{GC} / \mathrm{C}_{22}$ TMA-ASC electrodes fabricated in the same manner (inter-day reproducibility) have presented the response with an RSD of $6.59 \%$ during the voltammetric determination of $10 \mu \mathrm{M} \mathrm{NaNO}$.

Taking previously published reports on voltammetric sensors of nitrite into consideration (Table 2), it can be stated that $\mathrm{GC} / \mathrm{C}_{22} \mathrm{TMA}-\mathrm{ASC}$ indicates comparable and valuable analytical performance fitting within the limits of previous electrochemical sensors.

The evaluation of fabricated sensor stability is very important for the sensor's applicability. After the initial determination of nitrite, the $\mathrm{GC} / \mathrm{C}_{22} \mathrm{TMA}-\mathrm{ASC}$ electrode was stored in the buffer $(\mathrm{pH}=3.5)$ at room temperature. The electrochemical response for the detection of nitrite was regularly tested over 4 weeks (Fig. 6). For this purpose, 3 electrodes prepared in the same manner were tested parallelly $(n=3)$. After 4 weeks, the final current decreased by $23 \pm 4 \%$ of its initial value, which suggests that the electrode was reasonably stable during the test period. Good stability of the electrode can be achieved due to the hydrophobic property of the long alkyl chain that inhibits dissolution from the electrode surface. 
Table 2 An overview on recently reported nanomaterial-based electrochemical methods for the determination of nitrite

\begin{tabular}{|c|c|c|c|c|}
\hline Electrode & $\begin{array}{l}\text { LOD } \\
(\mu \mathrm{M})\end{array}$ & $\begin{array}{l}\text { Linear range } \\
(\mu \mathrm{M})\end{array}$ & 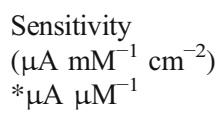 & Ref. \\
\hline AgPs-IL-CPE ${ }^{a}$ & 3.0 & $50-1000$ & - & [41] \\
\hline PEDOT-HMF ${ }^{\mathrm{b}}$ & 0.59 & $50-7500$ & 255.2 & {$[16]$} \\
\hline CoPcF-MWCNTs/GC & 0.062 & $0.096-340$ & - & {$[10]$} \\
\hline $\mathrm{GC} / \mathrm{SWCNT} / 3^{\mathrm{d}}$ & 1.08 & $5-200$ & 500 & {$[18]$} \\
\hline PDAP-NiHCF/GCE ${ }^{\mathrm{e}}$ & 0.0151 & $0.1-130$ & 7500 & {$[13]$} \\
\hline $\mathrm{Ag} / \mathrm{HNT} / \mathrm{MoS}_{2}-\mathrm{CPE}^{\mathrm{f}}$ & 0.70 & $2-425$ & 2900 & [5] \\
\hline $\mathrm{CR}-\mathrm{GO} / \mathrm{GCE}^{\mathrm{g}}$ & 1.00 & $8.9-167$ & - & {$[42]$} \\
\hline $\mathrm{Pd} / \mathrm{CoPc}^{\mathrm{h}}$ & 0.1 & $0.2-50$ and $500-5000$ & $0.01 *$ & {$[3]$} \\
\hline Ag-rGO/GCE ${ }^{\mathrm{i}}$ & 0.012 & $0.1-120$ & 18.4 & {$[6]$} \\
\hline $\mathrm{TiO}_{2} / \mathrm{CILE}^{\mathrm{j}}$ & 0.2 & $0.5-1500$ & - & {$[43]$} \\
\hline $\mathrm{POA} / \mathrm{IL}-\mathrm{CPE}^{\mathrm{k}}$ & 1.05 & $0.2-50$ & - & {$[44]$} \\
\hline 1-M-3-BIBr/CuO/SWCNTs/CPE ${ }^{\mathrm{m}}$ & 0.5 & $1.0-10,000$ & $0.0507 *$ & {$[11]$} \\
\hline $\mathrm{AuNPs} / \mathrm{Ti}_{3} \mathrm{C}_{2} \mathrm{~T}_{\mathrm{x}}-\mathrm{PDDA} / \mathrm{GCE}^{\mathrm{n}}$ & 0.059 & $0.1-2490$ and $2490-13,500$ & 250 & {$[12]$} \\
\hline $\mathrm{GC} / \mathrm{C}_{22} \mathrm{TMA}-\mathrm{ASC}$ & 0.1 & $0.5-50$ & 1185 & t.w. \\
\hline
\end{tabular}

${ }^{\text {a }}$ Silver particle-decorated carbon paste electrode based on IL

${ }^{\mathrm{b}}$ Poly(3,4-ethylenodioxythiophene) hollow microflowers

${ }^{\mathrm{c}}$ Glassy carbon electrode modified with tetrakis (3-trifluoromethylphenoxy) phthalocyaninato cobalt(II) on multiwalled carbon nanotubes

${ }^{\mathrm{d}}$ Glassy carbon electrode modified by single-walled carbon nanotubes and 2,3,7,8,12,13,17,18-Octakis $\{2$-[2-(3,5-dibutoxycarbonylphenoxy) ethoxy] ethylsulfanyl\} porphyrazinato nickel(II)

${ }^{\text {e }}$ Glassy carbon electrode modified by nickel hexacyanoferrate poly(2,6-diaminopyridine) hybrid

${ }^{\mathrm{f}}$ Silver/halloysite nanotube/molybdenum disulfide carbon paste electrode

${ }^{\mathrm{g}}$ Chemically reduced graphene oxide modified glassy carbon electrode

${ }^{\mathrm{h}}$ Glassy carbon electrode modified by cobalt phthalocyanine supported palladium nanoparticle composite

${ }^{\mathrm{i}}$ Glassy carbon electrode modified by nanocomposite of reduced graphene oxide decorated with silver nanoparticle

${ }^{\mathrm{j}}$ Titanium dioxide nanoparticles/IL composite electrode

${ }^{\mathrm{k}}$ Poly (o-anisidine) film at the surface of IL carbon paste electrode

${ }^{\mathrm{m}}$ Carbon paste electrode modified with 1-methyl-3-butylimidazolium bromide and $\mathrm{CuO}$ decorated single-wall carbon nanotubes

${ }^{\mathrm{n}}$ Gold nanoparticles deposited on poly (dimethyl diallyl ammonium chloride)-decorated MXene $\left(\mathrm{Ti}_{3} \mathrm{C}_{2} \mathrm{~T}_{\mathrm{x}}\right)$

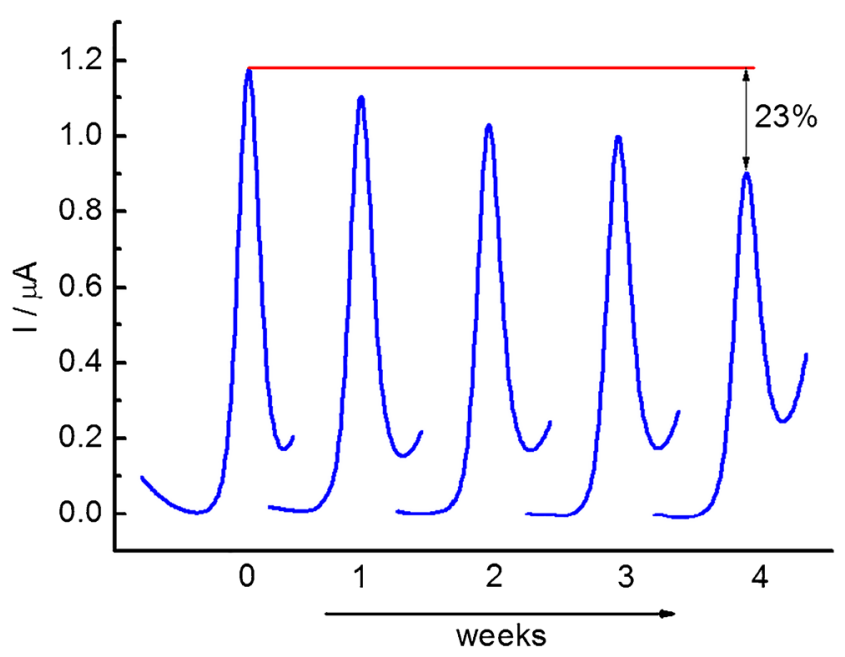

Fig. 6 DPV curves obtained using $\mathrm{GC} / \mathrm{C}_{22}$ TMA-ASC in the presence of $10 \mu \mathrm{M}$ of $\mathrm{NaNO}_{2}$ after $1,2,3$, and 4 weeks storage in buffer solution $(\mathrm{pH}=3.5)$

\section{Interference study}

The ability of selective sensing of $\mathrm{NaNO}_{2}$ at the $\mathrm{GC} / \mathrm{C}_{22} \mathrm{TMA}-$ ASC was evaluated in the presence of a mixture of interfering substances, such as ascorbic acid (AA), glucose (GLU), nitrate, and chloride. As shown in Fig. 7, apart from a welldefined voltammetric peak of nitrite, another peak at $0.22 \mathrm{~V}$ can be observed with increasing concentration of interferents. This peak derives from the AA oxidation. As demonstrated, the increasing interferent concentrations produced a gradual increase in the voltammetric peak of AA; however, even the presence of a 10-fold higher concentration of AA does not interfere with the voltammetric peak from $\mathrm{NaNO}_{2}$ oxidation. GLU cannot be oxidized at $\mathrm{GC} / \mathrm{C}_{22}$ TMA-ASC in the studied potential range. Besides, no $\mathrm{NaNO}_{2}$ signal changes were recorded with increasing concentrations of $\mathrm{NO}_{3}{ }^{-}$and $\mathrm{Cl}^{-}$. Additionally, the peak current of $5 \mu \mathrm{M}$ nitrite barely changed 


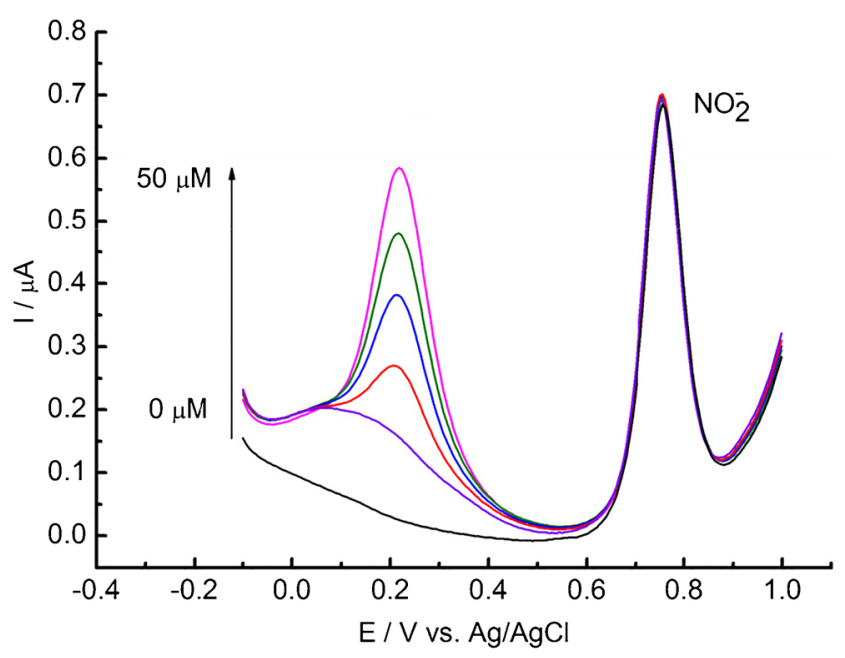

Fig. 7 DPV curves recorded at $\mathrm{GC} / \mathrm{C}_{22} \mathrm{TMA}-\mathrm{ASC}$ of the solution containing $5 \mu \mathrm{M}$ nitrite and the mixture of common interfering species (AA, $\mathrm{GLU}, \mathrm{NO}_{3}{ }^{-}$, and $\mathrm{Cl}^{-}$) with various concentrations of $0,10,20,30$, 40 , and $50 \mu \mathrm{M}$

having added 10-fold of catechol, hydroquinone, uric acid, ibuprofen, and $\mathrm{FeCl}_{3}$ (Fig. S4). However, the presence of $50 \mu \mathrm{M}$ of $\mathrm{Na}_{2} \mathrm{SO}_{3}$ enhances the nitrite peak current by $4.7 \%$. These results revealed that the $\mathrm{GC} / \mathrm{C}_{22} \mathrm{TMA}-\mathrm{ASC}$ sensor can be applied for the selective determination of nitrites in the presence of potential interferents.

\section{Determination of nitrite in commercial curing salts}

To investigate the applicability of the presented voltammetric sensor in real samples, the determinations of nitrite were performed in commercially available curing salts. Nitrite is the most frequently used additive to curing salts serving as a preservative $[6,9,17]$. The samples were purchased from a local supermarket, and the content of nitrites was determined by the standard addition method.

The representative standard addition plot is shown in Fig. S5. The values of the nitrite in the studied samples are collected in Table S1. As seen, the amounts of nitrates in curing salts are in all cases very close to $0.5 \mathrm{wt} \%$ in all cases. The results are in good agreement with the values given by the suppliers, which indicates that the sensor can be used for the determination of nitrite in various salt samples. Recovery studies were conducted on samples by nitrite standard added $(5 \mu \mathrm{M})$. The results imply good percent recoveries in the range from 100 to $104 \%$, hence indicating an accurate assay.

\section{Conclusion}

The conducted research has shown that $\mathrm{GC} / \mathrm{C}_{22}$ TMA-ASC electrode can be fabricated for the development of voltammetric nitrate sensors. The sensitive detection of nitrite was achieved due to the electrostatic interaction between positively charged ILs groups present on the electrode surfaces and negatively charged nitrite.

Each of the applied ILs increased the sensitivity of voltammetric nitrite determination in comparison to the unmodified GC electrode. The highest oxidation currents of nitrite were observed with the use of the electrode modified by the IL containing behenyl trimethylammonium cation and ascorbate anion $\left(\mathrm{GC} / \mathrm{C}_{22} \mathrm{TMA}-\mathrm{ASC}\right)$. The sensor demonstrated a reasonable detection limit, moderate linear concentration range, good reproducibility, high stability, and anti-interference ability. Besides, due to the simple preparation and easily renewable surface, the present approach can prove to be simple and versatile for further reference. The nitrite content in the cured salt samples tested ranges from 0.455 to $0.510 \%$ by weight.

It is essential for the proposed method to undergo further improvements in order to increase the linear range of the sensor and decrease the limit of detection. The approach presented in this paper, however, opens us up to the opportunity for further extended studies on various long alkyl chain ionic liquids for the design of high-performance electrochemical sensors. Making use of this approach for the determination of other compounds such as biomolecules, pollutants, and drugs remains a work in progress.

Supplementary Information The online version contains supplementary material available at https://doi.org/10.1007/s00604-021-04713-4.

Funding This study was supported by the Polish Ministry of Science and Higher Education Grant no. 0911/SBAD/0398. PP thanks the Polish Ministry of Science and Higher Education (Grant no. 03/31/SBAD/ 0384) for financial support.

\section{Compliance with ethical standards}

Conflict of interest The authors declare that they have no competing interests.

Open Access This article is licensed under a Creative Commons Attribution 4.0 International License, which permits use, sharing, adaptation, distribution and reproduction in any medium or format, as long as you give appropriate credit to the original author(s) and the source, provide a link to the Creative Commons licence, and indicate if changes were made. The images or other third party material in this article are included in the article's Creative Commons licence, unless indicated otherwise in a credit line to the material. If material is not included in the article's Creative Commons licence and your intended use is not permitted by statutory regulation or exceeds the permitted use, you will need to obtain permission directly from the copyright holder. To view a copy of this licence, visit http://creativecommons.org/licenses/by/4.0/.

\section{References}

1. Jo C, Ahn HJ, Son JH, Lee JW, Byun MW (2003) Packaging and irradiation effect on lipid oxidation, color, residual nitrite content, and nitrosamine formation in cooked pork sausage. Food Control 14:7-12 
2. Gligor D, Walcarius A (2014) Glassy carbon electrode modified with a film of poly(toluidine blue $\mathrm{O}$ ) and carbon nanotubes for nitrite detection. J Solid State Electrochem 18:1519-1528

3. Song X, Gao L, Li Y, Mao L, Yang JH (2017) A sensitive and selective electrochemical nitrite sensor based on a glassy carbon electrode modified with cobalt phthalocyanine-supported Pd nanoparticles. Anal Methods 9:3166-3171

4. Helaleh MIH, Korenaga T (2000) Ion chromatographic method for simultaneous determination of nitrate and nitrite in human saliva. $\mathrm{J}$ Chromatogr B Biomed Sci Appl 744:433-437

5. Ghanei-Motlagh M, Taher MA (2018) A novel electrochemical sensor based on silver/halloysite nanotube/molybdenum disulfide nanocomposite for efficient nitrite sensing. Biosens Bioelectron 109:279-285

6. Ahmad R, Mahmoudi T, Ahn MS, Yoo JY, Hahn YB (2018) Fabrication of sensitive non-enzymatic nitrite sensor using silverreduced graphene oxide nanocomposite. J Colloid Interface Sci 516:67-75

7. Astorga P, Canales C, Antilén M, Ramírez G (2014) Glassy carbon electrode modified with nickel (II) tetrasulfophtalocyanine films and its behavior as amperometric sensor for nitrite. Int $\mathbf{J}$ Electrochem Sci 9:109-119

8. Miranda KM, Espey MG, Wink DA (2001) A rapid, simple spectrophotometric method for simultaneous detection of nitrate and nitrite. Nitric Oxide 5:62-71

9. Jian JM, Fu L, Ji J, Lin L, Guo X, Ren TL (2018) Electrochemically reduced graphene oxide/gold nanoparticles composite modified screen-printed carbon electrode for effective electrocatalytic analysis of nitrite in foods. Sensor Actuat B Chem 262:125-136

10. Li P, Ding Y, Wang A, Zhou L, Wei S, Zhou Y, Tang Y, Chen Y, Cai C, Lu T (2013) Self-assembly of tetrakis (3trifluoromethylphenoxy) phthalocyaninato cobalt(II) on multiwalled carbon nanotubes and their amperometric sensing application for nitrite. ACS Appl Mater Interfaces 5:2255-2260

11. Bijad M, Karimi-Maleh H, Farsi M, Shahidi S-A (2017) Simultaneous determination of amaranth and nitrite in foodstuffs via electrochemical sensor based on carbon paste electrode modified with $\mathrm{CuO} / \mathrm{SWCNTs}$ and room temperature ionic liquid. Food Anal Methods 10:3773-3780

12. Wang Y, Zeng Z, Qiao J, Dong S, Liang Q, Shao S (2021) Ultrasensitive determination of nitrite based on electrochemical platform of AuNPs deposited on PDDA-modified MXene nanosheets. Talanta 221:121605

13. Wang X, Tan W, Ji H, Liu F, Wu D, Ma J, Kong Y (2018) Facile electrosynthesis of nickel hexacyanoferrate/poly(2,6diaminopyridine) hybrids as highly sensitive nitrite sensor. Sensor Actuat B Chem 264:240-248

14. Yuan M, Guo X, Li N, Li Q, Wang S, Liu C-S, Pang H (2019) Highly dispersed and stabilized nickel nanoparticle/silicon oxide/ nitrogendoped carbon composites for high-performance glucose electrocatalysis. Sensor Actuat B Chem 297:126809

15. Cao S, Zheng S, Pang H (2020) Ultrathin nanosheet-assembled accordion-like Ni-MOF for hydrazine hydrate amperometric sensing. Microchim Acta 187:168

16. Cheng Y-H, Kung C-W, Chou L-Y, Vittal R, Ho K-C (2014) Poly(3,4-ethylenedioxythiophene) (PEDOT) hollow microflowers and their application for nitrite sensing. Sensor Actuat B Chem 192: 762-768

17. Li J, Lin X (2007) Electrocatalytic reduction of nitrite at polypyrrole nanowire-platinum nanocluster modified glassy carbon electrode. Microchem J 87:41-46

18. Rębiś T, Falkowski M, Kryjewski M, Popenda L, Sobotta L, Jurga S, Marszall MP, Mielcarek J, Milczarek G, Goslinski T (2019) Single-walled carbon nanotube/sulfanyl porphyrazine hybrids deposited on glassy carbon electrode for sensitive determination of nitrites. Dyes Pigments 171:1-8
19. Wu YY, Li C, Dou ZY, Cui LL, Liu DJ, He XQ (2014) A novel nitrite sensor fabricated through anchoring nickel-tetrahydroxyphthalocyanine and polyethylene oxide film onto glassy carbon electrode by a two-step covalent modification approach. J Solid State Electrochem 18:2625-2635

20. Saeed AA, Singh B, Abbas MN, Issa YM, Dempsey E (2015) Electrocatalytic nitrite determination using iron phthalocyanine modified gold nanoparticles. Electroanalysis 27:1086-1096

21. Wu W, Li Y, Jin J, Wu H, Wang S, Ding Y, Ou J (2016) Sensing nitrite with a glassy carbon electrode modified with a threedimensional network consisting of $\mathrm{Ni}_{7} \mathrm{~S}_{6}$ and multi-walled carbon nanotubes. Microchim Acta 183:3159-3166

22. Moreira F, Santana ER, Spinelli A (2020) Ionic liquid-supported magnetite nanoparticles as electrode modifier materials for estrogens sensing. Sci Rep 10:1-11

23. Rosen BA, Salehi-Khojin A, Thorson MR, Zhu W, Whipple DT, Kenis PJA, Masel RI (2011) Ionic liquid - mediated selective conversion of $\mathrm{CO}_{2}$ to $\mathrm{CO}$ at low overpotentials. Science 334:643-644

24. Asran AM, Mohamed MA, Ahmed N, Banks CE, Allam NK (2020) An innovative electrochemical platform for the sensitive determination of the hepatitis B inhibitor Entecavir with ionic liquid as a mediator. J Mol Liq 302:112498

25. Bagheri H, Afkhami A, Khoshsafar H, Rezaei M, Sabounchei SJ, Sarlakifar M (2015) Simultaneous electrochemical sensing of thallium, lead and mercury using a novel ionic liquid/graphene modified electrode. Anal Chim Acta 870:56-66

26. Wang Q, Tang H, Xie Q, Tan L, Zhang Y, Li B, Yao S (2007) Room-temperature ionic liquids/multi-walled carbon nanotubes/ chitosan composite electrode for electrochemical analysis of NADH. Electrochim Acta 52:6630-6637

27. Wang L, Tricard S, Cao L, Liang Y, Zhao J, Fang J, Shen W (2015) Prussian blue/1-butyl-3-methylimidazolium tetrafluoroborate graphite felt electrodes for efficient electrocatalytic determination of nitrite. Sensor Actuat B Chem 214:70-75

28. Zhou L, Wang JP, Gai L, Li DJ, Bin Li Y (2013) An amperometric sensor based on ionic liquid and carbon nanotube modified composite electrode for the determination of nitrite in milk. Sensor Actuat B Chem 181:65-70

29. Niemczak M, Kaczmarek DK, Klejdysz T, Gwiazdowska D, Marchwińska K, Pernak J (2019) Ionic liquids derived from vita$\min \mathrm{C}$ as multifunctional active ingredients for sustainable storedproduct management. ACS Sustain Chem Eng 7:1072-1084

30. Saby C, Ortiz B, Champagne GY, Bélanger D (1997) Electrochemical modification of glassy carbon electrode using aromatic diazonium salts. 1. Blocking effect of 4-nitrophenyl and 4carboxyphenyl groups. Langmuir 13:6805-6813

31. Kibena E, Marandi M, Mäeorg U, Venarusso LB, Maia G, Matisen L, Kasikov A, Sammelselg V, Tammeveski K (2013) Electrochemical modification of gold electrodes with azobenzene derivatives by diazonium reduction. Chemphyschem 14:10431054

32. Griveau S, Pavez J, Zagal JH, Bedioui F (2001) Electro-oxidation of 2-mercaptoethanol on adsorbed monomeric and electropolymerized cobalt tetra-aminophthalocyanine films. Effect of film thickness. J. Electroanal Chem 497:75-83

33. Bibi S, Zaman MI, Niaz A, Rahim A, Nawaz M, Bilal Arian M (2019) Voltammetric determination of nitrite by using a multiwalled carbon nanotube paste electrode modified with chitosan-functionalized silver nanoparticles. Microchim Acta 186: $1-9$

34. Jiang L, Wang R, Li X, Jiang L, Lu G (2005) Electrochemical oxidation behavior of nitrite on a chitosan-carboxylated multiwall carbon nanotube modified electrode. Electrochem Commun 7:597601 
35. Wang P, Mai Z, Dai Z, Li Y, Zou X (2009) Construction of Au nanoparticles on choline chloride modified glassy carbon electrode for sensitive detection of nitrite. Biosens Bioelectron 24:3242-3247

36. Huang X, Li Y, Chen Y, Wang L (2008) Electrochemical determination of nitrite and iodate by use of gold nanoparticles/poly(3methylthiophene) composites coated glassy carbon electrode. Sensor Actuat B Chem 134:780-786

37. Zhang Y, Zhao Y, Yuan S, Wang H, He C (2013) Electrocatalysis and detection of nitrite on a reduced graphene/Pd nanocomposite modified glassy carbon electrode. Sensor Actuat B Chem 185:602 607

38. Wang H, Chen P, Wen F, Zhu Y, Zhang Y (2015) Flower-like $\mathrm{Fe}_{2} \mathrm{O}_{3} @ \mathrm{MoS}_{2}$ nanocomposite decorated glassy carbon electrode for the determination of nitrite. Sensor Actuat B Chem 220:749754

39. Guidelli R, Francesco P, Raspi G (1972) Voltammetric behavior of nitrite ion on platinum in neutral and weakly acidic media. Anal Chem 44:745-755

40. Spãtaru N, Rao TN, Tryk DA, Fujishima A (2001) Determination of nitrite and nitrogen oxides by anodic voltammetry at conductive diamond electrodes. J Electrochem Soc 148:E112
41. Menart E, Jovanovski V, Hočevar SB (2015) Silver particledecorated carbon paste electrode based on ionic liquid for improved determination of nitrite. Electrochem Commun 52:45-48

42. Mani V, Periasamy AP, Chen SM (2012) Highly selective amperometric nitrite sensor based on chemically reduced graphene oxide modified electrode. Electrochem Commun 17:75-78

43. Li Y, Wang H, Liu X, Guo L, Ji X, Wang L, Tian D, Yang X (2014) Nonenzymatic nitrite sensor based on a titanium dioxide nanoparticles/ionic liquid composite electrode. J Electroanal Chem 719:35-40

44. Ojani R, Raoof JB, Zamani S (2013) A novel and simple electrochemical sensor for electrocatalytic reduction of nitrite and oxidation of phenylhydrazine based on poly (o-anisidine) film using ionic liquid carbon paste electrode. Appl Surf Sci 271:98-104

Publisher's note Springer Nature remains neutral with regard to jurisdictional claims in published maps and institutional affiliations. 